\title{
Distribution of the Termite Reproductive Castes in Gunungpati, Semarang, Central Java
}

\author{
Niken Subekti*, Saniaturrohmah Saniaturrohmah \\ Department of Biology, Faculty of Mathematics and Natural Sciences, Universitas Negeri Semarang, Indonesia \\ *Email: nikensubekti@mail.unnes.ac.id
}

Submitted: 21 February 2020. Revised: 28 June 2020. Accepted: 7 August 2020

\begin{abstract}
Soil termites play a role as a primary decomposer in natural forests. These types of termites can be turned into residential pests as more land use to be plantations, housing, and buildings. This study analyzed the distribution of subterranean termites' reproductive caste, its identification, and environmental factors that influence the development of subterranean termites. The research methods used include distribution analysis using UV flying traps, surveys using GPS, identification of reproductive castes, and environmental factors including soil nutrients, vegetation analysis, temperature, soil moisture, air humidity, and wind speed. The results showed that the distribution of termites is found throughout the Gunungpati Semarang area. The identification of reproductive caste/alates found was Termitidae. Environmental factors that affect the life of termites in the Gunungpati Semarang area December 2019-January 2020 include the temperature of $27.0-28.4{ }^{\circ} \mathrm{C}$, the humidity of $60.2-61.2 \%$, air pressure $950.5-975.0 \mathrm{hPa}$, soil pH 4.84 5.60 and soil moisture 29.7-34.0\%. The vegetation was dominated by the Apocynaceae, Sapindaceae, and Euphorbiaceae. The highest value of diversity and vegetation index sequentially are Sekaran, Patemon, and Ngijo. It is found that the entire Gunungpati area of Semarang is a suitable habitat for the growth and development of the Termitidae. The finding will help the authoritative institution to consider Gunungpati as a conservation area.
\end{abstract}

Key words: Alates; Environment; Semarang; Termites

How to Cite: Subekti, N., \& Saniaturrohmah, S. (2020). Distribution of the Termite Reproductive Castes in Gunungpati, Semarang, Central Java. Biosaintifika: Journal of Biology \& Biology Education, 12 (2), 282-288

DOI: http://dx.doi.org/10.15294/biosaintifika.v12i2.25391

\section{INTRODUCTION}

Termites are social insects whose primary food is cellulose and lignocellulose found in putrefied wood, litter, and some fungi. There are 3000 species of termites in the world, mostly found in the tropics. The presence of termites as a primary decomposer in natural forests is highly dependent on soil $\mathrm{pH}$, moisture content, decomposition media, and food webs, and the surface area for colonization of microorganisms (Subekti et al., 2019).

Some types of termites devour plant material and wood used by humans so that an appropriate control system is needed. Termites also damage noncellulosic materials such as electronics, cables, telephone lines, and plantations. Losses caused by termites in Indonesia reach around 593,271.096 USD per year (Nandika et al., 2016).

Termites act as the main decomposer in natural forests. The termites' digestive organs do not have the cellulase to degrade cellulose; therefore, termites symbiotic with microorganisms live in its intestine. These microbes have the potential to degrade lignocellulose in their intestines. Bacteria in termite intestines are biological agents to degrade organic matter (Subekti, 2012a).

However, along with the development of the era, natural forests have experienced a land conversion to be plantations, high-rise buildings, and housings. Gunungpati Semarang area is a conservation buffer area. However, the area has now changed its function to become residentials, schools, and buildings. The termite as a primary decomposer then currently turns into a residential pest (Subekti, 2012b).

Research on building damage caused by termites in Semarang reached $44.58 \%$ (Subekti et al., 2018). Research on the potential distribution of termites in the Gunungpati Semarang area has never been done. Therefore, it is necessary to explore information on the potential distribution and identification of termites in Gunungpati Semarang. This study aimed to determine the distribution patterns and types of termites found in the Gunungpati Semarang area. The identification of soil termites can be done by flying traps or catching termite reproductive caste (alates). The termite reproductive caste (alates) flight, which comes out of the nest, aims to mate to maintain its survival. Alates have characteristics: they have eyes, scerosa, and exoskeleton, and have four wing membranes of the same size and shape. Alates are always interested in light sources (Carrijo and Cancello, 2011). The evolution of low-level termites usually has few groups, living in specific environmental conditions, and short seasons. Most of the low-level and high-level termites have pest potential. The existence of a reproductive caste for flight is greatly influ- 
enced by microenvironmental factors around the nest (Tong et al., 2017). The purpose of this study was to analyze the conditions of environmental factors in the Gunungpati area based on the identification of subterranean termites reproductive caste. Therefore, the innovations of this research are the distribution pattern, types of termite, and environmental factors that influence the existence of termites in the observed area. This research is beneficial for proper control of subterranean termites. The findings will also contribute to the decision of authoritative in considering a conservation area.

\section{METHODS}

This research was conducted in three villages in the Gunungpati region, Semarang, namely Ngijo, Patemon, and Sekaran. The research was started at the beginning of the rainy season, which is November 2019 - January 2020. Identification of reproductive caste and analysis of environmental data was made in the Biology Laboratory of the Faculty of Mathematics and Natural Sciences FMIPA Semarang State University.

This research was done in four steps, namely location survey and trap installation, sampling, identification of reproductive caste termites, and environmental data collection around the sampling point, including (temperature, humidity, air pressure, soil $\mathrm{pH}$, soil moisture, vegetation analysis, and soil nutrient content). Secondary data taken were rainfall and wind speed.

\section{Location and installation of UV- light trap}

The location was determined by the line transect method (Subekti et al., 2018). This survey would decide which points will be installed in a UV-light trap. The transect line was made along $4 \mathrm{~km}$, which includes three villages, namely Ngijo, Patemon, and Sekaran. Transects are $3 \mathrm{~m}$ wide and length to the end of the housing.

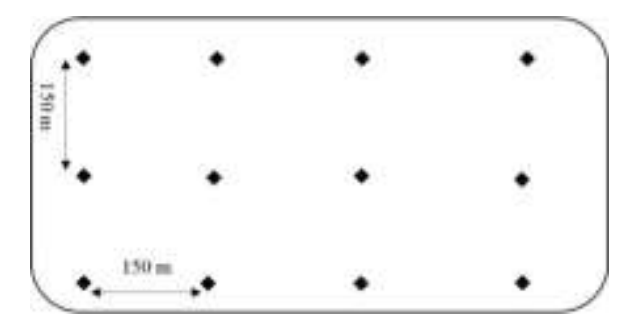

Figure 1. The UV-light trap installation

UV Light Trap traps were installed at designated locations. The distance between points was $150 \mathrm{~m}$ (Cheng et al., 2016). The trap used was UV Light Trap, with a power of 15 watts and a wavelength of
$365 \mathrm{~nm}$. UV-Light Trap was turned on starting at 18:00 - 24.00, with sampling every 30 minutes. As a control, LED lights with 15 watts of power at each sampling point were installed. Samples were observed every day from November 2019 - February 2020.

\section{Sampling}

The altitude and coordinates of the location of the sampling location were marked by GPS (Global Positioning System). Samples from each observation point were put into zip lock plastic. Plastic samples were labeled and then observed in a laboratory (Subekti et al., 2008).

\section{Identification of termite reproductive castes}

The reproductive caste from UV Light Trap was identified by using the Krishna and Weesner identification key. Alates were observed under a microscope with a magnification of $100 \mathrm{X}$, done by matching the characteristics of the wing found with the key of determination by Krishna and Weesner in Engel (2016) as follows: (a) observing the base of the wings (scale) to define the position of the scale of the front wings and stripes overlap or not, (b) analyzing the body wings color of the reproductive caste; brownish, dark, or transparent, (c) measuring the length of the larval body using a ruler, (d) Observing the structure of wing venation with a glass magnifier $(90 \mathrm{~mm}$ diameter) or a stereo microscope.

\section{Environmental data}

A thermohygrometer observed the temperature $\left({ }^{\circ} \mathrm{C}\right)$, air pressure $(\mathrm{hPa})$, and humidity $(\%)$. Soil moisture $(\%)$ and soil $\mathrm{pH}$ were measured using a soil tester. Vegetation data collection was carried out in 3 villages of the observed location. The importance value index of each tree was calculated by adding up the relative frequency, relative dominance, and relative density. The diversity index was analyzed using the Shannon-Wiener method.

\section{RESULTS AND DISCUSSION}

\section{Map of the distribution of termite reproductive castes in the Gunungpati, Semarang}

Figure 2 shows that at three locations of sampling points, 18 points were found for the distribution of termite reproductive caste. Ngijo area has 2 sample points, Patemon with 5 sample points, and Sekaran Village with 11 sample points. It shows that the distribution of termites is found in all research locations. Gunungpati is a suitable area for termite colonies. These types of termites have natural habitats in natural forests. However, with so many land conversions, these termites are found in residential locations and high-rise buildings. 


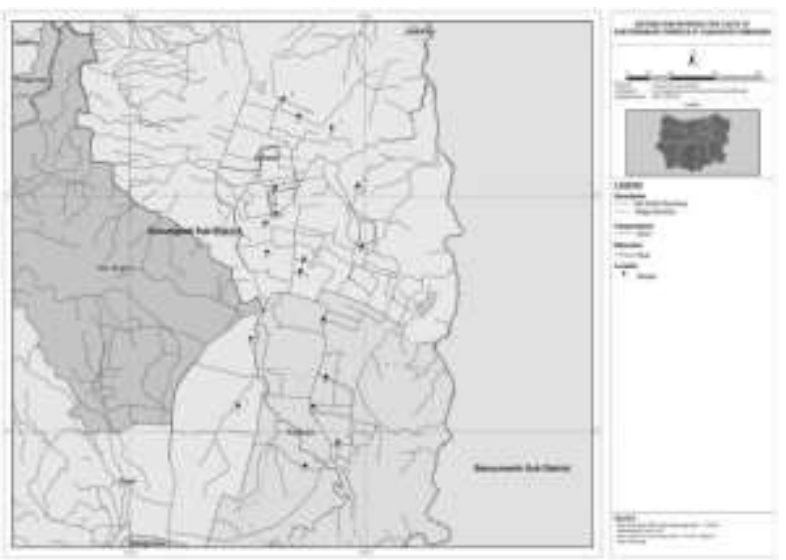

Figure 2. Distribution of termite reproductive castes in Gunungpati. The black flags are the sampling points at each location which were installed by UVlight trap.

\section{Identification of subterranean termites reproduc- tive caste}

The results found that all reproductive castes from UV light trap, all included in the Termitidae. It proves that the Termitidae colony dominated all sampling points. Termitidae is a group of low-level termites. In this kind of termite bodies, there is no cellulase enzyme. In its digestive tract, there are protozoa and other microorganisms to help degrade cellulose to be converted into substances that are useful for plants (Subekti et al., 2017). It means the Termitidae or lowlevel termites that dominate the Gunungpati area of Semarang. Termites of the Termitidae family are very useful in natural forests to help the process of degradation of organic matter into inorganic materials that are useful for plant growth (Susilowati, 2018). The appearance of termite reproductive caste identified is in Figure 3.

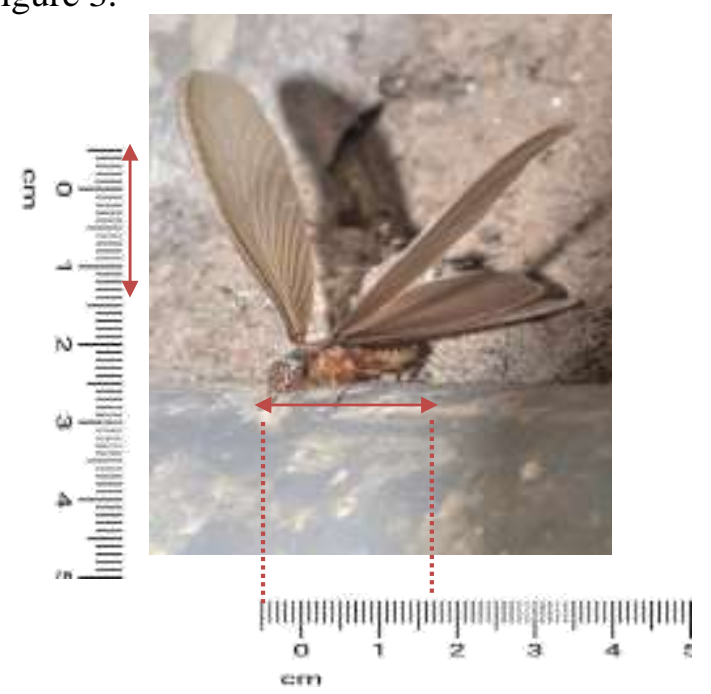

Figure 3. Termite reproductive caste identified (Termitidae) in centimeters. The body is usually longer than the wings

\section{Environmental factors that affect termite repro- ductive castes distribution}

Environmental factors that also influence the development of the termite population include rainfall, temperature, humidity, and food availability (Mugerwa et al., 2011). These factors interact and influence each other. Humidity and temperature are definite factors that together influence the activity of termites outside and inside the nest. Changes in environmental conditions will cause changes in the activities and behavior of the termites and habitat of its mound (Subekti, 2010).

Table 1. Average of environmental factors which affect soil termites' existence

\begin{tabular}{lccccc}
\hline \multicolumn{1}{c}{ Month } & \multicolumn{2}{c}{ TemperatureHumidity Air pressure $\mathrm{pH}$ Soil moisture } \\
& $\left({ }^{\circ} \mathrm{C}\right)$ & $(\%)$ & $(\mathrm{hPa})$ & of Soil & $(\%)$ \\
\hline December 2019 & $27.5-28.4$ & $60.5-61.2$ & $950.5-974.4$ & $4.8-5.0$ & $33.5-34.0$ \\
January 2020 & $27.0-28.3$ & $60.2-61,0$ & $960.0-975.05 .5-5.6$ & $29.7-29.8$ \\
\hline
\end{tabular}

The results showed that the area of Gunungpati, during observation time, Semarang has temperatures ranging from $28.33-28.4{ }^{\circ} \mathrm{C}$ so that termites can live and grow well there. Termite temperatures are needed for air changes inside and outside the nest. The temperature influences the activity of termite life, including foraging territory and alates flight activity. Previous research on building damage in Semarang city had been done by Subekti (2016) and confirmed that warm temperatures between $27-30{ }^{\circ} \mathrm{C}$, such as in the Gunungpati, are optimal temperatures for termite life . This temperature is classified as an effective temperature range for the life and activity of insects in an environment. Research on optimum temperature of subterranean termite habitat on forest of East America concluded that temperature can also affect the activity of soil termites as it is a component needed by termites for living and developing colonies (Maynard et al., 2015).

Air humidity affects the soil termite habitat. Moisture also affects the foraging territory of the termites. Optimum humidity that is preferred by termites ranges from $80-90 \%$ for the tropics. Meanwhile, the humidity of the Gunungpati Semarang area ranges from 61-61.2\%. Similar research has been also executed in Yanlappa forest, Bogor. The research proved that the explained condition has little effect on the behavior of termites hereabouts. However, soil termites are 
reliable architects in building nests so that even with low humidity, termites can quickly adapt to such conditions (Subekti, 2012a ).

Soil $\mathrm{pH}$ is an essential parameter in environmental factors because the soil and the organisms within it are very responsive to it. Gunungpati, Semarang, has a soil $\mathrm{pH}$ condition of 4.84-5.56. This $\mathrm{pH}$ is slightly acidic below neutral. Termites can still tolerate a slightly acidic condition. However, pH 6-7 is the optimal $\mathrm{pH}$ for the growth and development of termite life (Subekti, 2019). Similar studies were carried out on Odontotermes formosanus and Reticulitermes flavicep. The results showed that the two types of termites in China like a slightly acidic soil $\mathrm{pH}$ of 4.55.5, meanwhile, this type of termite can change the $\mathrm{pH}$ of the soil in the nest tends to be alkaline with a $\mathrm{pH}$ of 8.12-8.94. A research on optimum $\mathrm{pH}$ for subterranean termites assumed that the raise of $\mathrm{pH}$ in the mounds is caused by the activity of termite colonies itself (Li et al., 2017).

Air pressure is influenced by temperature, altitude, and the distribution of the ocean and land. Air pressure will decrease with altitude, air pressure rises and fall caused by differences in the time of rainfall in both the northern and southern parts of Indonesia. It is also supported by the research by Andinata, (2015). Fluctuations in air pressure in Gunungpati Semarang in December 2019 - January 2020 ranged from 974-
$975 \mathrm{hPa}$, which indicates the change in rainfall time in this region. This change greatly affected alates' flight time. The season and flight time of alates are strongly influenced by the microclimate factor of the local area. Thus, if air pressure fluctuates, the flight time will be delayed. A research on environmental factors that affect the flight of termite reproductive caste inferred that generally alates like warm temperatures and low humidity. But some argue that the factors affecting alates' flight are not only environmental factors but also intrinsic factors of termite colonies and biological clocks (Woon et al., 2019).

Soil moisture is an environmental factor that significantly affects the life of termites in the nest. The soil moisture in the Gunungpati Semarang area ranges from 29-34\%. Meanwhile, the optimal termite for termites is $70-90 \%$. This data shows that soil moisture in the Gunungpati region is not optimal for termite life. The effect of temperature inside and outside of the hive on subterranean termites had been observed by Axelsson and Andersson, (2012). The observation proved that soil moisture is needed by termite colonies to maintain a stable temperature in the nest. However, if the humidity outside the nest is not suitable for termites, then the termite will be able to regulate the humidity in the nest to maintain its colony.

Table 2. Average of environmental factors in Gunungpati

\begin{tabular}{lcc}
\hline Months & Rainfall $(\mathrm{mm})$ & Windspeed (m/s) \\
\hline December 2019 & $300-350$ & $4.8-4.9$ \\
January 2020 & $300-350$ & $5.1-5.5$
\end{tabular}

Source: BMKG (Meteorological, Climatological, and Geophysical Agency) Semarang, 2020

Based on the data in Table 2, obtained from BMKG Semarang in December 2019-January 2020, the average rainfall in the Gunungpati Semarang area was $300-350 \mathrm{~mm} / \mathrm{month}$. This data shows that the area of Gunungpati Semarang has optimal rainfall for termite life. Rainfall is very influential in the development of termites and is useful for stimulating the release of reproductive caste from the nest. Similar research was done in forest of Mt. Slamet and concluded that the Termitidae prefers low rainfall, while the type of Schedorinotermes javanicus is still able to withstand high rainfall (Pratikno et al., 2018). The spread of termites is related to temperature and rainfall, so that most types of termites are found in the lowlands of the tropics. Precipitation that is too high can also reduce alates' flight activity. Alates do not come out if rainfall is low. Effect of rainfall on subterranean termites' colony has been studied by oleh Subekti, (2016) and inferred that high intensity of rainfall could also diminish the activity of termites.
Rainfall generally has a direct physical influence on the life of termite colonies, especially those that build nests in or on the surface of the land

Gunungpati wind speed in December 2019January 2020 was $4.97 \mathrm{~m} / \mathrm{s}$. This shows that the area of Gunungpati Semarang has suitable wind speed for termites. The optimal wind speed for termite reproductive caste flight is $3-4 \mathrm{~m} / \mathrm{s}$. Wind speed dramatically affects the life of termites above ground level and alates flight. Research on subterranean termites of France concluded that wind speed, temperature, and light intensity are microclimatic factors that significantly affect the flight time of alates (Mullins et al., 2015). an increase or decrease in wind speed does not affect the decrease in temperature in the nest. A research conducted in Northern Namibia showed that Macrotermes michalseni moved downward under natural conditions, unfavorable environmental conditions, such as strong winds, and the temperature in the nest. Such impacts are more dense mounds, with 
few internal channels, the decreasing temperature in the nest (Fagundes et al., 2020).

Table 3. Data of vegetation at three regions of Gunungpati, Semarang Central Java

\begin{tabular}{|c|c|c|c|}
\hline \multicolumn{2}{|c|}{ LocationFamily } & $\begin{array}{c}\text { Importance } \\
\text { Value Index } \\
\text { (IVI) }\end{array}$ & $\begin{array}{l}\text { Diversity } \\
\text { index }\left(\mathrm{H}^{\prime}\right)\end{array}$ \\
\hline \multirow{5}{*}{ Ngijo } & Myrtaceae & 0.32 & 0.24 \\
\hline & Arecaceae & 0.35 & 0.25 \\
\hline & Anacardiaceae & 0.36 & 0.25 \\
\hline & Lamiaceae & 0.55 & 0.31 \\
\hline & Euphorbiaceae & 0.75 & 0.35 \\
\hline \multirow{3}{*}{\multicolumn{2}{|c|}{$\begin{array}{c}\text { Caricaceae } \\
\text { Sapindaceae } \\
\text { Patemon Arecaceae }\end{array}$}} & 0.33 & 0.24 \\
\hline & & 0.37 & 0.26 \\
\hline & & 0.39 & 0.27 \\
\hline \multicolumn{2}{|c|}{$\begin{array}{r}\text { Patemon Arecaceae } \\
\text { Meliaceae }\end{array}$} & 0.45 & 0.28 \\
\hline & Sapindaceae & 0.79 & 0.35 \\
\hline \multirow{4}{*}{ Sekaran } & Arecaceae & 0.79 & 0.35 \\
\hline & Apocynaceae & 1.55 & 0.34 \\
\hline & Annonaceae & 0.36 & 0.25 \\
\hline & Bixaceae & 0.31 & 0.23 \\
\hline
\end{tabular}

Table 3 shows that in Ngijo Village, the dominant vegetation is the Euphorbiaceae family with the highest IVI and H' of 0.75 and 0.35. In Patemon, the dominating vegetation is the Sapindaceae with the highest IVI and H' of 0.79 and 0.35 . In contrast, in Sekaran village, the dominant vegetation is the Apocynaceae family with the highest IVI and $\mathrm{H}$ ' of 1.55 and 0.35 for the Arecaceae family. This shows that at 3 locations, the sampling points dominated by different vegetation. The vegetation also influences the point of discovery of the research sample, Sekaran found 11 sample points, followed by Patemon with 5 sample points and Ngijo with 2 sample points. It means that Sekaran with Apocynaceae vegetation dominated by more termite colonies compared to other villages which dominated by Sapindaceae, and Euphorbiaceae families.

The vegetation type is very influential on the development of termites, and this is because termites require cellulose from the roots of plants that creep into termite nests. Coincident research done in Bogor forest and showed that plants' root is a food source for termite, and the plants will keep alive since only little parts are eaten by termites, while remaining parts could still absorb organic materials in the nest (Subekti, 2012).

The variety of importance value and diversity index is also caused by the amount of vegetation found. The difference in the amount of vegetation causes different air humidity. Similar research was also carried out on the analysis of plant vegetation in the natural forests of Gunung Meja, Papua. The research stated that the plant diversity index and plant vegetation analysis in West Papua are related to the diversity of soil termites within it (Subekti et al., 2018). The difference in the amount of vegetation dramatically influences the growth and development of the surrounding termite colonies. The more amount of vegetation found the more food sources are available for termites. Research on effect of subterranean termites' colony on the soil around the hives was done by Subekti, (2016). The research confirmed that the more termite colonies, the more nutrients, and minerals for plants around them. So there is a mutually beneficial symbiotic relationship between plants and soil termite colonies.

Table 4. Analysis of soil chemical components in Gunungpati

\begin{tabular}{llll}
\multicolumn{2}{l}{ Parameters } & \multicolumn{2}{l}{ Results (\%) } \\
\cline { 2 - 4 } & Ngijo & Patemon & Sekaran \\
\hline C-Organik 1.50 & 0.94 & 2.14 \\
N-Total & 0.16 & 0.13 & 0.30 \\
P-Total & 0.07 & 0.06 & 0.10 \\
K-Total & 0.05 & 0.10 & 0.06 \\
\hline
\end{tabular}

As shown in Table 4, the organic $\mathrm{C}$ found in Sekaran is higher and confirms that it is more fertile than others. Organic material is from the degradation of organic materials such as plants, animals, and microorganisms. A research by Cardoso et al., (2013), state that fertile soil has a balance state of biodiversity and high productivity organic compound. Fertile soil has higher $\mathrm{C}$ compound than infertile soil. Production of organic $\mathrm{C}$ will provide the energy needed by plants on the ground

The $\mathrm{N}$ found in Sekaran is also the highest compared to others. It indicates that Sekaran is more fertile than others. Nitrogen has a crucial role in the environment as complex nitrogen, such as nitrate and nitrite involve in food webs. Similar research done at Dryland ecosystem in Italy which found that $\mathrm{N}$ element has crucial role for plant growth in producing plants biomass on it. Nitrogen in the cycle serves to protect the environment Mineralization, and nitrogen fixation processes, as well as a symbiosis with microbes, release small molecules for plants to grow and develop (Costantini et al., 2016).

$\mathrm{P}$ level in Sekaran is higher than others, meaning that it is more fertile among other areas. Research on soil aggregate has been done Bunemann et al., (2018), who found that soil aggregate has excellent porosity and organic matter ( $\mathrm{N}, \mathrm{P}$ and $\mathrm{K})$, as well as water capacity. The elements will have a kind of symbiosis with soil microbes to produce minerals needed for plant growth. The $\mathrm{P}$ level affects water capacity in the soil and soil density. The total P ele- 
ment in the soil is used in food webs so that the $\mathrm{P}$ element will be used as a soil mineral for plants' growth on the soil.

$\mathrm{K}$ 's highest level in Sekaran finds that the area is also more fertile. It is an essential element for plants to develop properly. Research on the $\mathrm{K}$ element in several soils of Germany showed that soil with well grown plants has higher $\mathrm{K}$ content compared to the $\mathrm{K}$ content in soil with shed plants. Soil temperatures found were in the range of $60-80{ }^{\circ} \mathrm{F}$. The results of the study concluded that the $\mathrm{K}$ content depends on soil moisture, soil aeration, and temperature (Mouhamad et al., 2016).

Termite colony like soils with high organic matter content. Clay types usually have high organic matter content. A research by Sarcinelli et al., (2013) found that Soil termites can select organic soil particles from the outside in the nest so that soil particles that are rich in nutrients are more abundant than sand particles. That is due to soil with high organic matter will more quickly degrade inorganic compounds into organic compounds needed by plants to absorb nutrients. Results on a research by Ali et al., (2013) inferred that soil termites as primary decomposers have an essential role in degrading organic matter into inorganic materials with the help of microbes and soil arthropods.

A similar study was done in Brazil on the soil termite Coptotermes gestroi. The results showed that the level of eating preference of $C$. gestroi did not affect environmental factors, including temperature, temperature, and humidity. However, in summer, the eating preference of $C$. gestroi is more than in winter and spring. A research by Santos et al., (2010) found that the colony of $C$. gestroi could quickly acclimatize environmental change.

Soil organic matter greatly determines the population density of soil organisms, one of which is soil fauna, the higher the soil organic content the more diverse soil fauna that found in an ecosystem. A study by Siebers et al., (2015) claimed that the composition and type of leaf litter determine the type of soil fauna present in the area, and the amount of litter available determines the density of soil fauna. Organic material is the remains of plants and animals of soil organisms, both decomposed and decomposed.

Termites could be the indicator of ecosystem damage. A research on subterranean termites in forest conducted by Subekti et al., (2019) found that the recovery of a damaged ecosystem could be seen from the increase in termite colonies with parameters of colony abundance, composition, biomass, species distribution, and diversity of termite species. Decreasing the value of the canopy allows direct sunlight to the ground surface. Environmental changes will occur with an increase in the value of the canopy. A research by Cornelius and Osbrink, (2011) concluded that increased air humidity and decreased environmental temperature also can form microclimates around the nest. Variations in daily temperature and high humidity will affect the activity of soil termites. Habitat disturbance affects the improvement of microhabitat quality in an ecosystem. Results of a study by (2011) stated that the decrease in termite habitat will affect the termite food supply and the ability to make nests. A decrease in the value of bulk density will cause the soil to become dense and decrease the activity of termites, especially soil termites.

The innovations of this research are the current distribution pattern, types of termite, and environmental factors that influence the existence of termites in the observed area. Therefore, this research offers innovative subterranean termite control technology by flying traps at a certain wavelength frequency based on the identification of subterranean termites in Gunungpati by its reproductive caste. The findings would be beneficial in considering whether the Gunungpati area is a well-maintained or degraded ecosystem. It also provides recommendations for policymakers to designate Gunungpati as a conservation buffer area.

\section{CONCLUSION}

The results showed that the Termitidae family dominated termites reproductive castes distribution in the Gunungpati, Semarang, Central Java. The highest vegetation analysis was successively in Sekaran, Patemon, and Ngijo. Environmental factors that affect the life and development of the Termitidae include fertile soil with rich nutrients, temperature of 28.3 $28.4^{\circ} \mathrm{C}$, the humidity of $61.0-61.2 \%$, air pressure of $974.4 \mathrm{hPa}$, soil $\mathrm{pH}$ in 4.8 - 5.5 and soil moisture existence of subterranean termites in the observed area is a bioindicator of the ecosystem. The findings recommend Gunungpati to be a conservation area.

\section{REFERENCES}

Ali, I.G., Sheridan, G., French, R.J., and Ahmed, B.M. (2013). Ecological Benefits of Termite Soil Interaction and Microbial Symbiosis in the Soil Ecosystem. Journal of Earth Sciences and Geotechnical Engineering, 3(4), 63-85

Andinata, P. S. (2015). Pola Spasial dan Temporal Klimatologis Tekanan Udara Permukaan Wilayah Indonesia. Bogor: Institut Pertanian Bogor.

Axelsson, E.P and Andersson, J. (2012). A Case Study of Termite Mound Occurrence in Relation to Forest Edges and Canopy Cover within the Barandabhar 
Forest Corridor in Nepal. International Journal of Biodiversity and Conservation, 4(15), 633-641

Bunemann, E.K., Bongiorno, G., Bai, Z., Creamer, R.E, Deyn, G.D., Goede, R.D., Fleskens, L., Geissen, V., Kuyper, T.W., Mader, P., Pulleman, M., Sukkel, W., Groenigen, J.W.V., and Brussaard, L. (2018). Soil Biology and Soil quality - A critical review.Biochemistry 120 (2018), 105-125

Cardoso, E.J.BN., Vasconcellos, R.L.F., Bini, D., Miyauchi, M.Y.H., Santos, C.A.D., Alves, P.R.L., Paula, A.M.D., Nakatani, A.S., Pereira, J.D.M., and Nogueira, M. A. (2013). Soil Health: Looking for Suitable Indicators. What Should Be Considered to Assess The Effects of Use and Management on Soil Health. Sci. Agric., 70 (4), 274-289

Costantini, E.A.C., Branquinho, C., Nunes A., Schwilch, G., Stavi, I., Valdecantos A., and Zucca, C. (2016). Soil Indicators to Assess the Effectiveness of Restoration Strategies in Dryland Ecosystems. Solid Earth, 7 (2016), 397-414.

Carrijo, T.F., and Cancello, E.M. (2011). Divinotermes (Isoptera, Termitidae, Termitinae), a New Genus from South America. Sociobiology, 58(3), 537-556.

Cornelius, M.L., and Osbrink, W.L.A. (2011). Effect of Seasonal Changes in Soil Temperature and Moisture on Wood Consumption and Foraging Activity of Formosan Subterranean Termite (Isoptera: Rhinotermitidae). Journal of Economic Entomology, 4(3), 1024- 1030.

Fagundes, T.M, Ordonez, J.C., and Yaghoobian, N. (2020). How the Thermal Environment Shapes the Structure Of Termite Mounds. R. Soc. open sci. 7, 191332.

Li, Y., Dong, Z.Y., Pan, D.Z., and Chen, L.H. (2017). Effect of Termite on Soil $\mathrm{pH}$ and Its Applica on for Termite Control in Zhejiang Province, China. Sociobiology. 64(3), 317-326.

Maynard, D.S., Crowther, T.W., King, J.R., Warren, R.J., and Bradford, M.A.. (2015). Temperate Forest Termites: Ecology, Biogeography, and Ecosystem Impacts. Ecological Entomology 40 (2015), 199-210.

Mugerwa, S., Nyangito, M., Mpairwe, D., and Nderitu, J. (2011). Effect of biotic and abiotic factors on composition and foraging intensity of subterranean termites. African Journal of Environmental Science and Technology, 5(8), 579-588.

Mouhamad, R., Alsaede, A., and Iqbal, M. (2016). Behavior of Potassium in Soil: A mini- review. Chemistry International 2(1), 58-69.

Mullins, A.J., Messenger, M.T., Hochmair, H.H., Tonini, F., Su, N.Y., and Riegel, C. (2015). Dispersal Flights of the Formosan Subterranean Termite (Isop- tera: Rhinotermitidae). J. Econ. Entomol., 108(2), 113.

Nandika, D., Rismayadi, Y. and Diba, F. (2016). RAYAP Biologi dan Pengendaliannya, $2 n d$ ed.; Mubin N. (Ed). Muhammadiyah University Press: Surakarta.

Pratikno, H. Ahmad, I., and Budianto, B.H. (2018). Diversity and Abundance of Termites Along Altitudinal Gradient and Slopes in Mount Slamet, Central Java, Indonesia. Biodiversitas. 19 (5), 1649-1658.

Pribadi, T., Raffiudin, R., and Harahap, I.S. (2011). Termites Community as Environmental Bioindicators in Highlands: A Case Study in Eastern Slopes of Mount Slamet, Central Java. Biodeiversitas Journal of Biological Biodiversity, 12 (3): 235-240.

Santos, M.N., Teixeira, M.L.F, Pereira M.B, and Menezes, E.B. (2010). Environmental Factors Fnfuencing the Foraging And Feeding Behavior of Two Termite Species (Isoptera: Rhinotermitidae) in Natural Habitats. Sociobiology, 55 (3), 763-777.

Sarcinelli, T.S., Chaefer, C.E.G.R., Filho, E.I.F., and Neri, A.V. (2013). Soil Modification by Termites in A Sandy-Soil Vegetation in the Brazilian Atlantic rain forest. Journal of Tropical Ecology, 29 (2013), 439-448.

Siebers, N., Martius, C., Eckhardt, K.U., Garcia, M.V.B., Leinweber, P., and Amelung, W. (2015). Origin and alteration of organic matter in termite mounds from different feeding guilds of the amazon rainforests. PLoS ONE, 10(4), e0123790. DOI:10.1371/journal.

Subekti, N. (2012a). Organic material and soil mineral accumulation from mound building of subterranean termites Macrotermes gilvus Hagen (blattodea: termitidae). Biosaintifika, 4(1), 10-17.

Subekti, N. (2012b). Insect diversity of tinjomoyo forest, semarang city, central java. Jurnal Tengkawang, $1(2), 19-26$.

Subekti, N., Priyon, B., and Aisyah, A,N. (2018). Biodiversity of Termites and Damage Building in Semarang, Indonesia. Biosaintifika, 10(1), 176-182.

Subekti, N. (2010). Karakteristik Populasi Rayap Tanah Coptotermes spp (blattodea: rhinotermitidae) dan Dampak Serangannya. Biosaintifika 2(2), 110-114.

Subekti, N., Nurvaizah , Nunaki, J.H., Wambraw, H.L., and Mar' ah R. (2018). Biodiversity and Distribution of Termite Nests in West Papua, Indonesia. Biodiversitas, 19 (4), 1659- 1664

Subekti, N., Widiyaningrum, P., Nandika, D., and Solihin, D.D. (2019). Colony Composition and Biomass of Macrotermes gilvus Hagen (blattodea: termitidae) in Indonesia. IIUM Engineering Journal, 20(1), 24-28 